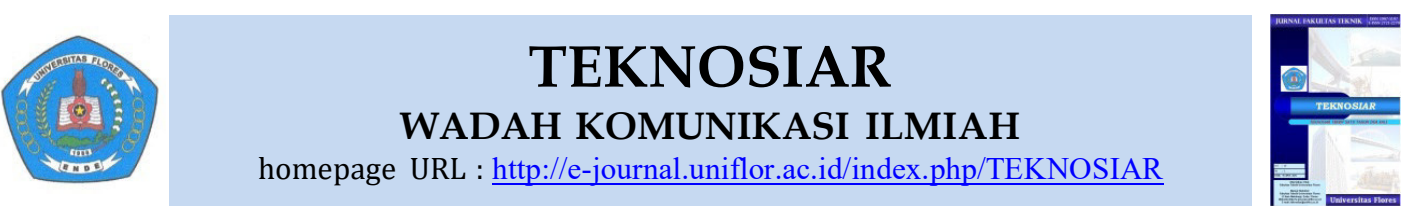

\title{
Pengaruh Penggunaan Tepung Bata Ringan Pada Campuran Beton Terhadap Kuat Tekan dan Kuat Tarik Belah Beton
}

\author{
Meiske Cunradiana ${ }^{1}, *$ F.X.Ndale ${ }^{2}$, Yohanes Laka Suku ${ }^{3}$ \\ ${ }^{1}$ Alumni Program Studi Teknik Sipil, Fakultas Teknik, Universitas Flores, Ende \\ ${ }^{2,3}$ Program Studi Teknik Sipil, Fakultas Teknik, Universitas Flores, Ende \\ *) Correspondence, e-mail: milanonet66@gmail.com
}

Received: 27-03-2020 Revised: 04-04-2020 Accepted: 15-04-2020

\begin{abstract}
ABSTRAC
Concrete is a composite building material consisting of a certain size combination of coarse aggregate, fine aggregate, water and cement. Various attempts have been made to increase the strength of the concrete by modifying its arrangement such as lightweight concrete, spray concrete, fiber concrete, high strength concrete, very high strength concrete, self-compressed concrete, etc. For certain purposes, sometimes mixed concrete is added with chemical and mineral additives. The addition of chemicals or minerals is expected to change the performance and properties of the concrete mixture according to the desired conditions and objectives. The purpose of this study was to determine the effect of variations and levels of light brick flour in the concrete mixture on compressive strength and split tensile strength of concrete. This study uses the Indonesian National Standard (SNI) method. The results obtained by the maximum compressive strength of concrete is $23.66 \mathrm{MPa}$ and the maximum tensile strength of concrete is $4.38 \mathrm{MPa}$ with a percentage of $10 \%$ flour at the age of 28 days which has met and exceeds the compressive strength and tensile strength of the planned concrete. $f^{\prime} \mathrm{c} 20 \mathrm{MPa}$. The optimum level of $10 \%$ light brick flour can increase the compressive strength and tensile strength of concrete. This is inversely proportional to the percentage of $30 \%$ and the results obtained by $50 \%$ tend to experience a decrease in strength.
\end{abstract}

Keywords: concrete, compressive strength, tensile strength, light brick flour

\begin{abstract}
ABSTRAK
Beton adalah suatu bahan bangunan komposit yang terdiri atas kombinasi ukuran tertentu dari agregat kasar, agregat halus, air dan semen. Berbagai upaya telah dilakukan untuk meningkatkan kekuatan beton dengan memodifikasi penyusunannya seperti beton ringan, beton semprot(shotcrete)t, beton fiber, beton mutu tinggi, beton mutu sangat tinggi, beton mampat sendiri, dll. Untuk keperluan tertentu terkadang campuran beton ditambahkan dengan bahan aditif kimia dan mineral. Penambahan bahan performa atau mineral diharapkan dapat mengubah kinerja dan sifat campuran beton sesuai kondisi dan tujuan yang diinginkan. Tujuan penelitian ini adalah untuk mengetahui pengaruh variasi dan kadar tepung bata ringan dalam campuran beton terhadap kuat tekan dan kuat tarik belah beton. Penelitian ini menggunakan metode Standar Nasional Indonesia (SNI). Hasil yang diperoleh kuat tekan maksimum beton adalah 23,66 MPa dan kuat tarik maksimum beton 4,38 MPa dengan persentase 10\% tepung pada umur 28 hari yang telah memenuhi dan melebihi kuat tekan dan kuat tarik yang direncanakan. beton. $f^{\prime} c 20$ MPa. Kadar optimum tepung bata ringan 10\% dapat meningkatkan kuat tekan dan kuat tarik beton. Hal ini berbanding terbalik dengan persentase $30 \%$ dan hasil yang didapat sebesar $50 \%$ cenderung mengalami penurunan kekuatan.
\end{abstract}

Kata kunci: beton,kuat tekan,kuat tarik,tepung bata ringan

TEKNOSIAR Volume 14, No.01, April 2020

p-ISSN 1907-5197 (versi cetak) e-ISSN 2721-2270 (versi online) 


\section{PENDAHULUAN}

Beton merupakan bahan bangunan komposit yang terdiri dari kombinasi dengan ukuran tertentu antara agregat kasar, halus, air dan semen. Beton dalam kondisi basah dapat dibentuk berbagai macam model, dan beton yang telah mengeras membentuk material seperti batu. Beton digunakan untuk membuat berbagai macam konstruksi seperti perkerasan jalan, struktur bangunan, pondasi, dan jembatan.

Untuk keperluan tertentu terkadang campuran beton masih ditambahkan bahan tambah berupa zatzat kimia tambahan (chemical additive) dan mineral,material tambahan. Salah satu upaya dalam meningkatkan performa dan sifat-sifat campuran beton sesuai dengan kondisi dan tujuan yang diinginkan,adalah dengan penambahan tepung bata ringan dengan mengacu pada standar pemberian bahan tambahan beton yang diatur dalam SNI S-18-1990-03 tentang Spesifikasi Bahan Tambahan pada Beton.

Penambahan tepung dalam penelitian ini diperoleh dari limbah proyek pembangunan yang tidak terpakai karena rusak saat proses pengerjaan berlangsung. Bentuk pecahan bata ringan juga bervariasi tergantung tingkat kerusakan yang terjadi pada saat proses pengerjaan. Seiringan dengan hal ini untuk memanfaatkan kembali limbah bata ringan, maka peneliti melakukan penambahan pecahan bata ringan yang akan dihaluskan menjadi tepung (agregat sangat halus) pada campuran beton saat proses pengadukan sedang berlangsung. Penelitian penggunaan material dengan ukuran partikel sangat halus sebagai bahan penyusun beton seperti abu terbang, silica fume, dan tepung marmer terbukti berhasil dalam meningkatkan sifat mekanik beton normal, beton mutu tinggi dan reactive powder concrete (Kushartomo et al., 2013).

Tujuan penelitian ini untuk mengetahui pengaruh variasi dan kadar tepung bata ringan pada campuran beton terhadap kuat tekan dan kuat tarik belah beton.

\section{Tinjauan Pustaka}

Penelitian tentang beton dengan campuran pecahan bata ringan sudah pernah dilakukan oleh peneliti sebelumnya dengan judul;Analisis pengaruh penambahan pecahan bata ringan sebagai pengganti sebagian agregat halus terhadap kuat tekan beton. Penambahan pecahan bata ringan untuk mengganti sebagian agregat halus dengan variasi $0 \%, 5 \%, 10 \%, 15 \%$ dan $20 \%$. Hasil kuat tekan beton maksimal dari variasi pecahan bata ringan sebesar $0 \%$ sampai $20 \%$ pada umur 28 hari sebesar 16,176 $\mathrm{MPa}$, melebihi kuat tekan yang telah direncanakan yaitu $\mathrm{f}^{\prime} \mathrm{c}=14,5 \mathrm{Mpa}$. (Yulian;Yudha;Adhityatama,2016)

\section{Bahan}

Bahan-bahan pembentuk beton adalah gabungan atau sekumpulan interaksi mekanis dan kimiawi dari material pembentuknya yang terdiri dari bahan semen portland, agregat kasar (kerikil), agregat halus (pasir) dan air. Bahan-bahan dasar seperti semen dan air yang bereaksi secara kimiawi kemudian mengikat butiran-butiran menjadi satu kesatuan yang utuh. Keawetan, kekuatan dan sifat-sifat lain dari beton tergantung dari bahan-bahan dasarnya. Untuk menjamin agar beton yang dihasilkan memenuhi persyaratan yang diminta, terlebih dahulu agregat yang akan digunakan, diuji sebelum perancangan campuran. Jenis pengujian bahan seperti pada Tabel 1 dan Tabel 2 dibawah ini:

Tabel 1. Pengujian Agregat Kasar

\begin{tabular}{|c|c|c|c|}
\hline No. & Percobaan & Standar & Nilai \\
\hline 1 & Gradasi Butiran & SNI 03-1968-1990 & \\
\hline 2 & Kelembaban & SNI 03-1968-1990 & \\
\hline 3 & Berat Volume & ASTM C 29-78 & \\
\hline
\end{tabular}

TEKNOSIAR Volume 14, No.01, April 2020

p-ISSN 1907-5197 (versi cetak) e-ISSN 2721-2270 (versi online) 
Meiske Cunradiana,F.X.Ndale, Yohanes Laka Suku

Pengaruh Penggunaan Tepung Bata Ringan Pada Campuran Beton Terhadap Kuat Tekan dan Kuat Tarik Belah Beton

\begin{tabular}{llll}
\hline 4 & Kadar Keausan & SNI 03-2417-1991 & $\leq 27 \%$ \\
\hline 5 & Berat Jenis (SSD) & SNI 03-1968-1990 & $2,5-2,7 \mathrm{Kg} / \mathrm{dm}^{3}$ \\
\hline 6 & Penyerapan Air & SNI 03-1968-1990 & - \\
\hline 7 & Kadar Lumpur & SNI 03-4142-1996 & $\leq 5 \%$ \\
\hline 8 & Fine Modulus (FM) & SNI 03-1968-1990 & \\
\hline
\end{tabular}

Tabel 2. Pengujian Agregat Halus

\begin{tabular}{|c|c|c|c|}
\hline No. & Percobaan & Standar & Nilai \\
\hline 1 & Gradasi Butiran & ASTM C $136-78$ & \\
\hline 2 & Kelembaban & ASTM C 556-71 & $5 \%$ \\
\hline 3 & Berat Volume & ASTM C $136-78$ & $\leq 95$ \\
\hline 4 & Volume Pengembangan & ASTM C 556-71 & - \\
\hline 5 & Berat Jenis (SSD) & ASTM C 136-78 & $2,5-2,7 \mathrm{Kg} / \mathrm{dm}^{3}$ \\
\hline 6 & Kadar Lumpur & SNI 03-4142-1996 & $\leq 5 \%$ \\
\hline 7 & Fine Modulus (FM) & ASTM C 136-78 & \\
\hline
\end{tabular}

Tepung bata ringan merupakan suatu bahan tambah berupa zat additive yang dicampurkan ke mortar beton. Tepung bata ringan juga merupakan hasil dari proses penghancuran bongkahan bata ringan yang difungsikan untuk kombinasi beton. Tepung bata ringan bisa dikatakan memiliki volume yang banyak dan masih dalam tahap pengembangan untuk mengurangi penggunaan pasir atau semen dalam adukan beton. Kegunaan dari tepung bata ringan adalah untuk mencegah keretakan pada beton apabila sudah mengering. Karena dengan adanya tepung bata ringan akan mengurangi penyusutan yang terjadi mulai dari percetakan hingga pengeringan.

\section{Kekuatan Beton}

Sifat-sifat utama beton yang berhubungan dengan kepentingan praktisnya adalah mengenai kekuatan, karakteristik, tegangan-regangan, penyusutan dan deformasi, respon terhadap suhu, daya serap air, dan ketahanannya. Diantara sifat-sifat beton yang paling mendapat perhatian adalah kekuatan beton, karena hal tersebut yang merupakan gambaran umum mengenai kualitas beton. Faktor-faktor yang mempengaruhi kekuatan beton dari bahan penyusunnya ditentukan oleh faktor air semen, porositas dan faktor-faktor intrinsik lainnya seperti kekuatan agregat, kekuatan pasta semen, kekuatan ikatan/lekatan antara semen dengan agregat.

\section{Kuat Tekan Beton}

Kuat tekan beton merupakan ciri terpenting dari kuat tidaknya beton. Kuat tekan beton sangat tergantung pada aktifitas agregat, tingkat kesempurnaan campuran beton, kondisi pengeras menghasilkan kuat tekan rata-rata yang memenuhi syarat. Semakin rendah perbandingan air semen, semakin tinggi kekuatan tekannya. Kuat tekan merupakan suatu parameter yang menunjukkan besarnya beban persatuan luas yang menyebabkan benda uji hancur oleh gaya tekan tertentu. Kuat tekan dengan uji silinder dapat dilihat pada Gambar 1 dan dapat ditentukan dengan persamaan (1) (SNI 1974-2011):

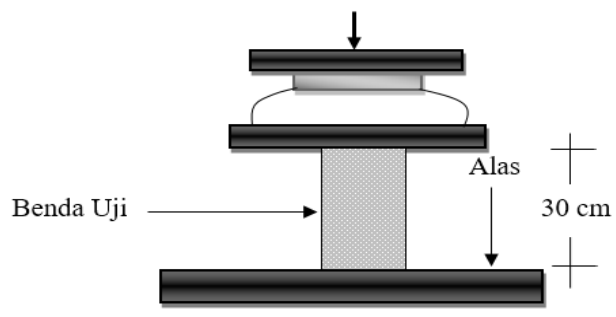

Gambar 1. Pengujian Kuat Tekan Beton

TEKNOSIAR Volume 14, No.01, April 2020

p-ISSN 1907-5197 (versi cetak) e-ISSN 2721-2270 (versi online) 
Besarnya kuat tekan beton dapat menggunakan persamaan berikut:

$1=-$

Dimana :

$$
\begin{array}{ll}
f^{\prime} c & =\text { Kuat tekan benda uji selinder beton }(\mathrm{Mpa}) \\
\mathrm{P} & =\text { Beban tekan beton }(\mathrm{N}) \\
\mathrm{A} & =\text { Luas penampang benda uji }\left(\mathrm{mm}^{2}\right)
\end{array}
$$

Kuat Tarik Belah Beton

Kekuatan tarik belah beton relative rendah, kira-kira $10-15 \%$ dari kekuatan tekannya. Pendekatan yang baik untuk menghitung kekuatan tarik beton $f^{\prime} c t$ adalah dengan rumus $0,1 f^{\prime} c<f^{\prime} c t<0,2 f^{\prime} c$. Kekuatan tarik lebih sulit diukur dibandingkan dengan kekuatan tekan bila dengan beban-beban aksial langsung dan masalah penjepitan (gripping) pada mesin. Sehingga untuk mengetahui kuat tarik beton dalam pengujian hanya dapat diukur dengan metode uji keruntuhan (modulus of rupture) dan metode uji belah silinder.(Nawy 1998:41). Kuat tarik belah beton yang diperoleh dengan uji pembelahan silinder dilakukan dengan memberikan beban tekan secara merata diseluruh bagian panjang dari silinder hingga terbelah dua dari ujung ke ujung. Kuat tarik dengan uji belah silinder dapat dilihat pada Gambar 2 dan dapat ditentukan dengan persamaan (2) (SNI 03-24912002):

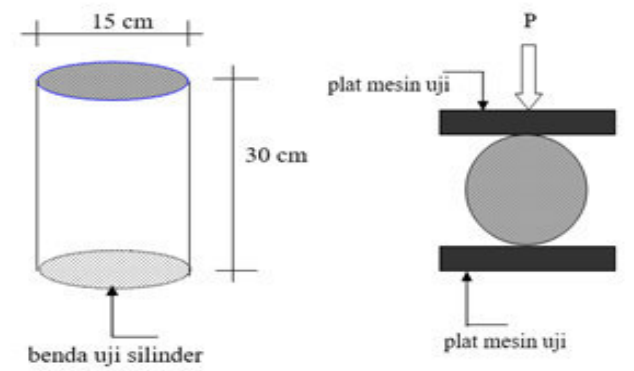

Gambar 2. Pengujian Kuat Tarik Belah Beton

Besarnya kuat tarik beton dapat menggunakan persamaan berikut ini:

$=-$

Dimana :

$$
\begin{array}{ll}
f c t & =\text { Kuat Tarik Belah Beton }(\mathrm{Mpa}) \\
\mathrm{P} & =\text { Beban Maksimum }(\mathrm{N}) \\
\mathrm{L} & =\text { Panjang Benda Uji Silinder }(\mathrm{mm}) \\
d & =\text { Diameter Silinder }(\mathrm{mm}) .
\end{array}
$$

Nilai pendekatan yang diperoleh dari hasil pengujian berulangkali mencapai kekuatan $0,05-0,6$ kali ${ }^{\prime}$, sehingga untuk beton normal digunakan 0,57 ${ }^{\prime}$, (Nawy 1998:43).

Alasan utama dari kuat tarik yang kecil bahwa pada kenyataannya beton dipenuhi retak-retak halus yang tidak dipengaruhi bila beton menerima beban tekan karena beban tekan menyebabkan retak menutup sehingga memungkinkan terjadinya penyaluran tekan, berbeda jika beton menerima beban tarik.

\section{METODE}

\section{Bahan dan Alat}

TEKNOSIAR Volume 14, No.01, April 2020 
Bahan yang digunakan terdiri dari agregat kasar, agregat halus dan tepung bata ringan berasal dari wilayah Kabupaten Ende. Sedangkan alat yang digunakan tersedia di Laboratorium Program Studi Teknik Sipil Fakultas Teknik, Universitas Flores.

\section{Pemeriksaan Bahan}

Penelitian dimulai dari pengambilan sampel agregat kasar, agregat halus dan tepung bata ringan. Pegambilan dengan cara acak, selanjutnya dibawah ke laboratorium guna mewakili dari masingmasing material. Tahapan awal dimulai dari pengujian agregat kasar dan halus yaitu; Pengujian abrasi, bertujuan untuk mendapatkan nilai keausan agregat kasar dengan menggunakan mesin Los Angeles. Pengujian Gradasi pengujian ini bertujuan untuk memperoleh pembagian butiran dengan mengunakan saringan. Selanjutnya dilakukan pengujian berat jenis yang bertujuan untuk memperoleh Saturated Surface Dry (SSD) atau jenuh kering permukaan.Untuk mendapatkan nilai serapan air pada material maka perlu dilakukan pengujian absorbsi, yang terakhir pengujian kadar lumpur, bertujuan untuk memperoleh kandungan lumpur, dengan menggunakan saringan no. 200.

\section{Perancangan Beton}

Perencanaan campuran beton kuat tekan rencana f'c 20 MPa, menggunakan metode SNI 03-28342000, pembuatan benda uji berbentuk silinder $15 \mathrm{~cm}$ x $30 \mathrm{~cm}$, dilakukan test setelah umur beton 7 dan 28 hari.

Tabel 3. Jumlah Benda Uji

\begin{tabular}{|c|c|c|c|c|c|c|c|}
\hline \multirow[t]{2}{*}{ No } & \multirow[t]{2}{*}{ Jenis Pengujian } & \multirow{2}{*}{$\begin{array}{l}\text { Umur } \\
\text { Pengujian }\end{array}$} & \multicolumn{4}{|c|}{$\%$ Tepung Bata Ringan } & \multirow[t]{2}{*}{ Jumlah } \\
\hline & & & $0 \%$ & $10 \%$ & $30 \%$ & $50 \%$ & \\
\hline \multirow[t]{2}{*}{1} & \multirow[t]{2}{*}{ Kuat Tekan } & 7 hari & 3 & 3 & 3 & 3 & 12 \\
\hline & & 28 hari & 3 & 3 & 3 & 3 & 12 \\
\hline \multirow[t]{2}{*}{2} & \multirow{2}{*}{$\begin{array}{l}\text { Kuat Tarik } \\
\text { Belah }\end{array}$} & 7 hari & 3 & 3 & 3 & 3 & 12 \\
\hline & & 28 hari & 3 & 3 & 3 & 3 & 12 \\
\hline \multicolumn{2}{|c|}{ Total } & & & & & & 48 \\
\hline
\end{tabular}

Sumber:Hasil olahan peneliti

\section{Pengujian Benda Uji}

Data hasil pengujian diolah dan dianalisa lebih lanjut guna memperoleh hasil yang dapat disimpulkan.

\section{HASIL DAN PEMBAHASAN}

\section{Sifat-Sifat Bahan}

Tabel 4. Hasil Analisa Agregat Kasar

\begin{tabular}{lllll}
\hline No. & \multicolumn{1}{c}{ Percobaan } & \multicolumn{1}{c}{ Hasil } & \multicolumn{1}{c}{ Standar } & \multicolumn{1}{c}{ Nilai } \\
\hline 1 & Gradasi Butiran & $12,70-25.40 \mathrm{~mm}$ & SNI 03-1968-1990 & \\
\hline 2 & Kelembaban & $2.4 \%$ & SNI 03-1968-1990 & \\
\hline 3 & Berat Volume & $1.33 \mathrm{gram} / \mathrm{cm}^{3}$ & ASTM C 29-78 & - \\
\hline 4 & Kadar Keausan & $22.88 \%$ & SNI 03-2417-1991 & $\leq 27 \%$ \\
\hline 5 & Berat Jenis (SSD) & 2.52 & SNI 03-1968-1990 & $2,5-2,7 \mathrm{Kg} / \mathrm{dm}^{3}$ \\
\hline 6 & Penyerapan Air & $3.6 \%$ & SNI 03-1968-1990 & - \\
\hline 7 & Kadar Lumpur & $0.2 \%$ & SNI 03-4142-1996 & $\leq 5 \%$ \\
\hline 8 & Fine Modulus (FM) & 4,38 & SNI 03-1968-1990 & \\
\hline Sumber & Hasil Analisis & & &
\end{tabular}

Hasil Analisa agregat kasar dari Tabel 4 menunjukkan bahwa gradasi butiran berkisar 12,70 $25,40 \mathrm{~mm}$, tingkat kelembaban berkisar 2,4\%,kadar keausan 22,88\% memenuhi standar $\leq 27 \%$, Berat jenis dalam kondisi SSD sebesar 2,52 juga memenuhi standar di kisaran 2,5 sampai dengan

TEKNOSIAR Volume 14, No.01, April 2020 
$2,7 \mathrm{Kg} / \mathrm{dm}^{3}$.Nilai penyerapan air dan nilai berat volume juga memenuhi standar,kadar lumpur dibawah $\leq 5 \%$ dan nilai Fine Modulus sebesar 4,38

Tabel 5. Hasil Analisa Agregat Halus

\begin{tabular}{cllll}
\hline No. & \multicolumn{1}{c}{ Percobaan } & \multicolumn{1}{c}{ Hasil } & \multicolumn{1}{c}{ Standar } & Nilai \\
\hline 1 & Gradasi Butiran & Zona 1 & ASTM C 136-78 & \\
\hline 2 & Kelembaban & $2.26 \%$ & ASTM C 556-71 & $5 \%$ \\
\hline 3 & Berat Volume & 1.48 gram/cm3 & ASTM C 136-78 & $\leq 95$ \\
\hline 4 & Volume Pengembangan & $9.54 \%$ & ASTM C 556-71 & - \\
\hline 5 & Berat Jenis (SSD) & 2.13 & ASTM C 136-78 & $2,5-2,7 \mathrm{Kg} / \mathrm{dm}^{3}$ \\
\hline 6 & Kadar Lumpur & $3.09 \%$ & SNI 03-4142-1996 & $\leq 5 \%$ \\
\hline 7 & Fine Modulus & 3.29 & ASTM C 136-78 & \\
\hline Sumber $:$ Hasil Analisis & & &
\end{tabular}

Hasil analisa agregat halus dari Tabel 5 menunjukkan bahwa gradasi butiran masuk dalam Zona1,tingkat kelembaban agregat,berat volume,dan volume pengembangan telah memenuhi spesifikasi, sedangkan berat jenis agregat dalam kondisi SSD sebesar 2,13 nilai ini masuk di antara $2,5-2,7 \mathrm{Kg} / \mathrm{dm}^{3}$ dari standar yang ditentukan,nilai kadar lumpur dibawah $\leq 5 \%$ dan nilai Fine Modulus sebesar 3,29.

\section{Kekuatan Beton}

Tabel 6. Hasil Analisis Kuat Tekan Beton

\begin{tabular}{ccccc}
\hline $\begin{array}{c}\text { Umur } \\
\text { (hari) }\end{array}$ & $\begin{array}{c}\text { Variasi } \\
\text { Tepung (\%) }\end{array}$ & $\begin{array}{c}\text { Rekapitulasi hasil kuat } \\
\text { tekan (Mpa) }\end{array}$ & $\begin{array}{c}\text { Perubahan kuat } \\
\text { tekan (Mpa) }\end{array}$ & $\begin{array}{c}\text { Perubahan Kuat } \\
\text { Tekan (\%) }\end{array}$ \\
\hline 7 & 0 & 18,76 & 0 & 0,00 \\
\cline { 2 - 5 } & 10 & 19,61 & 0,85 & 4,53 \\
\cline { 2 - 5 } & 30 & 15,08 & $-3,68$ & $-19,62$ \\
\hline 28 & 7,16 & $-11,6$ & $-61,83$ \\
\hline & 0 & 20,93 & 0 & 0,00 \\
& 10 & 23,66 & 2,73 & 13,04 \\
\hline & 30 & 8,67 & $-12,26$ & $-58,58$ \\
\hline & 50 & 6,32 & $-14,61$ & $-69,80$ \\
\hline
\end{tabular}

Sumber : Hasil Analisis

Hasil analisa pada Tabel 6, kuat tekan beton normal dan beton dengan tambahan tepung bata ringan diatas menunjukkan bahwa penambahan tepung bata ringan sebesar $10 \%$ dapat meningkatkan kuat tekan beton sebesar $4,53 \%$ pada umur 7 hari dan 13,05\% pada umur 28 hari, sedangkan penambahan tepung bata ringan $30 \%$ dan $50 \%$ kuat tekan beton mengalami penurunan.

Tabel 7 Hasil Analisis Kuat Tarik Belah Beton

\begin{tabular}{ccccc}
\hline $\begin{array}{c}\text { Umur } \\
\text { (hari) }\end{array}$ & $\begin{array}{c}\text { Variasi } \\
\text { tepung (\%) }\end{array}$ & $\begin{array}{c}\text { Rekapitulasi hasil Kuat } \\
\text { Tarik Belah (Mpa) }\end{array}$ & $\begin{array}{c}\text { Perubahan Kuat } \\
\text { Tarik Belah (Mpa) }\end{array}$ & $\begin{array}{c}\text { Perubahan Kuat } \\
\text { Tarik Belah (\%) }\end{array}$ \\
\hline 7 & 0 & 2,49 & 0 & 0 \\
\cline { 2 - 5 } & 10 & 3,44 & 0,95 & 38,15 \\
& 30 & 2,49 & 0 & 0 \\
\hline 28 & 0 & 2,21 & $-0,28$ & $-11,24$ \\
\hline & 50 & 3,53 & 0 & 0,00 \\
\hline
\end{tabular}

TEKNOSIAR Volume 14, No.01, April 2020

p-ISSN 1907-5197 (versi cetak) e-ISSN 2721-2270 (versi online) 
Meiske Cunradiana,F.X.Ndale, Yohanes Laka Suku

Pengaruh Penggunaan Tepung Bata Ringan Pada Campuran Beton Terhadap Kuat Tekan dan Kuat Tarik Belah Beton

\begin{tabular}{ccccc}
\hline 10 & 4,38 & 0,85 & 24,08 \\
\hline 30 & 2,30 & $-1,23$ & $-34,84$ \\
\hline 50 & 2,21 & $-1,32$ & $-37,39$ \\
\hline
\end{tabular}

Sumber : Hasil Analisis

Hasil analisa pada Tabel 7, kuat tarik belah beton normal dan beton dengan tambahan tepung bata ringan diatas menunjukkan bahwa penambahan tepung bata ringan sebesar $10 \%$ dapat meningkatkan kuat tarik belah beton sebesar 38,15\% pada umur 7 hari dan $24,08 \%$ pada umur 28 hari, sedangkan penambahan tepung bata ringan $30 \%$ dan $50 \%$ kuat tarik belah beton mengalami penurunan.

\section{KESIMPULAN}

Berdasarkan hasil analisis dan pembahasan, maka dapat disimpulkan sebagai berikut :

1. Kuat tekan beton maksimum sebesar 23,66 $\mathrm{MPa}$ dan kuat tarik belah beton maksimum sebesar 4,38 $\mathrm{MPa}$ dengan kandungan tepung $10 \%$ pada umur 28 hari telah memenuhi dan melampaui kuat tekan dan tarik belah beton yang direncanakan f'c $20 \mathrm{MPa}$.

2. Kadar optimum tepung bata ringan $10 \%$ dapat meningkatkan kuat tekan dan kuat tarik belah beton. Hal ini berbanding terbalik dengan persentase penambahan tepung $30 \%$ dan $50 \%$ hasil yang diperoleh cenderung mengalami penurunan kekuatan.

\section{UCAPAN TERIMA KASIH}

1. Terima kasih kepada Kepala Laboratorium Teknik Sipil Universitas Flores

2. Terima kasih kepada pihak-pihak yang telah membantu dalam proses penelitian

\section{DAFTAR PUSTAKA}

ASTM Internasional. (2002). Standar Test Method for Compressive Strength of Concrete, Section 4, Vol.04.02, ASTM C39.

ASTM Internasional. (2002). Standar Test Method for Flexural Strength of Clyndrical Speciments, Section 4, Vol.04.02, ASTM C78.

ASTM Internasional. (2002). Standar Test Method for Splitting Tensile Strength of Clyndrical Concrete Speciments, Section 4, Vol.04.02, ASTM C496.

Badan Standarisasi Nasional. (2011). SNI 03-4431-2011. Cara Uji Kuat Lentur Beton Nasional dengan Dua Titik Pembebanan. Bandung: Badan Standarisasi Nasional.

Badan Standarisasi Nasional. (1990). SNI S-18-1990-03. Spesifikasi Bahan Tambahan Pada Beton. Jakarta: Badan Standarisasi Nasional.

Basuki.(2018). Bata Ringan. Diambil pada tanggal 14 Oktober 2018 dari https://id.wikipedia.org/wiki/Bataringan.

Mulyono, T. (2005). Teknologi Beton. Yogyakarta: Andi.

Purwati. (2014). Pengaruh Ukuran Butiran Terhadap Kuat Tekan Dan Modulus Elastisitas Beton Kinerja Tinggi Grade 80. Jurnal Arsitektur Universitas Bandar Lampung.

Yulian Yudha Adhityatama. (2016). Analisis pengaruh penambahan pecahan bata ringan sebagai pengganti sebagian agregat halus terhadap kuat tekan beton.

TEKNOSIAR Volume 14, No.01, April 2020

p-ISSN 1907-5197 (versi cetak) e-ISSN 2721-2270 (versi online) 
Susilowati. (2011). Pemanfaatan Serbuk Marmer Sebagai Bahan Alternatif Pengganti Semen Pada Campuran Beton Normal. Jurnal Arsitektur Universitas Bandar Lampung.

Rani Oktaviani Tarru. Studi Penggunaan Silica Fume Sebagai Bahan Pengisi (Filler) Pada Campuran Beton.: Program Studi Teknik Sipil, Fakultas Teknik, Universitas Kristen Indonesia Toraja.

TEKNOSIAR Volume 14, No.01, April 2020 